\title{
Human equilibrative nucleoside transporter 1 and Notch 3 can predict gemcitabine effects in patients with unresectable pancreatic
} cancer

\author{
K Eto ${ }^{1,4}$, H Kawakami ${ }^{* 1,4}$, M Kuwatani ${ }^{1}$, T Kudo ${ }^{1}$, Y Abe ${ }^{1}$, S Kawahata ${ }^{1}$, A Takasawa ${ }^{2}$, M Fukuoka ${ }^{2}$, \\ Y Matsuno ${ }^{2}$, M Asaka $^{3}$ and N Sakamoto ${ }^{1}$ \\ ${ }^{1}$ Department of Gastroenterology and Hepatology, Hokkaido University Graduate School of Medicine, Kita 15, Nishi 7, Kita-ku, \\ Sapporo 060-8638, Japan; ${ }^{2}$ Department of Surgical Pathology, Hokkaido University Hospital, Sapporo, Japan and ${ }^{3}$ Department of \\ Cancer Preventive Medicine, Hokkaido University Graduate School of Medicine, Sapporo, Japan
}

Background: Pancreatic ductal carcinoma (PDC) is one of the most lethal human carcinomas. Expression patterns of some genes may predict gemcitabine (GEM) treatment efficacy. We examined predictive indicators of survival in GEM-treated patients by quantifying the expression of several genes in pre-treatment endoscopic ultrasound-guided fine-needle aspiration (EUS-FNA) samples from patients with PDC.

Methods: The expressions of human equilibrative nucleoside transporter 1 (hENT1), deoxycitidine kinase, ribonucleoside reductase 1, ribonucleoside reductase 2 and Notch3 in EUS-FNA tissue samples from 71 patients with unresectable PDC were quantified using real-time reverse transcription-polymerase chain reactions and examined for correlations with GEM sensitivity.

Results: The log-rank test detected no significant differences in overall survival between GEM-treated patients with low and high mRNA levels of all genes examined. However, low Notch3 mRNA expression was significantly associated with longer overall survival in a multivariate analysis for survival $(P=0.0094)$. High $h E N T 1$ expression level was significantly associated with a longer time to progression ( $P=0.039$ ). Interaction tests for GEM administration and hENT1 or Notch3 mRNA expression were statistically significant $(P=0.0054$ and 0.0047 , respectively).

Conclusion: hENT1 and Notch3 mRNA expressions in EUS-FNA specimens were the key predictive biomarkers of GEM effect and GEM sensitivity in patients with unresectable PDC.

Pancreatic ductal carcinoma (PDC) is one of the most lethal human cancers. Pancreatic ductal carcinomas are usually unresectable (80-90\%) at the time of diagnosis, despite recent progress in imaging modalities. Gemcitabine (GEM) has been the standard first-line chemotherapy agent for unresectable PDC (Burris et al, 1997). Only 10-20\% of patients with PDC are candidates for curative resection (Matsuno et al, 2004). Even if curative resection is performed, the postoperative 5-year survival rate is only $15-25 \%$ because of a high rate of recurrence (Wagner et al, 2004). Recently, two randomised clinical phase III trials of adjuvant chemotherapy (AC) for PDC showed significant increases in overall survival (OS) and disease-free survival (DFS) (Neoptolemos et al, 2004; Oettle et al, 2007). Therefore, AC is important for patients with PDC. If GEM could be appropriately and selectively administered to

\footnotetext{
*Correspondence: Dr H Kawakami; E-mail: hiropon@med.hokudai.ac.jp
}

${ }^{4}$ These authors contributed equally to this work

Received 29 October 2012; revised 21 December 2012; accepted 19 February 2013; published online 14 March 2013 
patients with GEM sensitivity based on the expression of genes in the tumour, maximal chemotherapy efficacy could be achieved without subjecting GEM-resistant patients to unnecessary side effects.

Recent investigations using cell lines or surgical specimens have revealed that the expression of several genes may be predictors of GEM efficacy in GEM-treated patients. Such GEM efficacy predictor genes include human equilibrative nucleoside transporter 1 ( $h E N T 1)$, the major mediator of GEM uptake in human cells (Farrell et al, 2009); GEM-metabolism-related enzymes such as deoxycitidine kinase (dCK) (Maréchal et al, 2010); GEM resistance-related enzymes such as ribonucleoside reductase 1 (RRM1) (Nakahira et al, 2007), ribonucleoside reductase 2 (RRM2) (Itoi et al, 2007) and Notch3 (Yao and Qian, 2010), which is related to GEM-induced caspase-mediated apoptosis. Ashida et al (2009) and Itoi et al (2007) demonstrated that levels of expression of these genes correlated with GEM sensitivity in patients with unresectable PDC. The aim of this study was to determine a predictive indicator of survival and GEM sensitivity in GEM-treated patients with unresectable PDC by examining gene expression in pre-treated tissue biopsy samples obtained by endoscopic ultrasound-guided fine-needle aspiration (EUS-FNA).

\section{MATERIALS AND METHODS}

Patients. The study included 185 consecutive patients in whom pancreatic masses had been identified by abdominal ultrasound or computed tomography and who underwent EUS-FNA at Hokkaido Hospital between October 2007 and September 2010. Subjects were excluded if they had an extrapancreatic mass, tumour histology other than ductal adenocarcinoma or preoperative evidence of resectable PDC. Finally, the analysed population comprised a consecutive series of 71 patients (Figure 1).

EUS-FNA procedure. Endoscopic ultrasound was performed using an oblique forward-viewing electronic linear scanning video echoendoscope equipped with an elevator and a 3.7-mm-diameter working channel (GF-UCT240-AL5; Olympus Medical Systems Co., Ltd, Tokyo, Japan). The echoendoscope was connected to a processor with a colour Doppler function (SSD-5500; HitachiAloka Medical., Ltd, Tokyo, Japan). EUS-FNA was performed before treatment, as described previously (Itoi et al, 2005). Briefly, the lesions were identified using B-mode imaging. The absence of vessels in the target area was confirmed with the colour Doppler mode. After determination of an adequate angle to the tumour, an aspiration needle was introduced into the lesion. While suction was

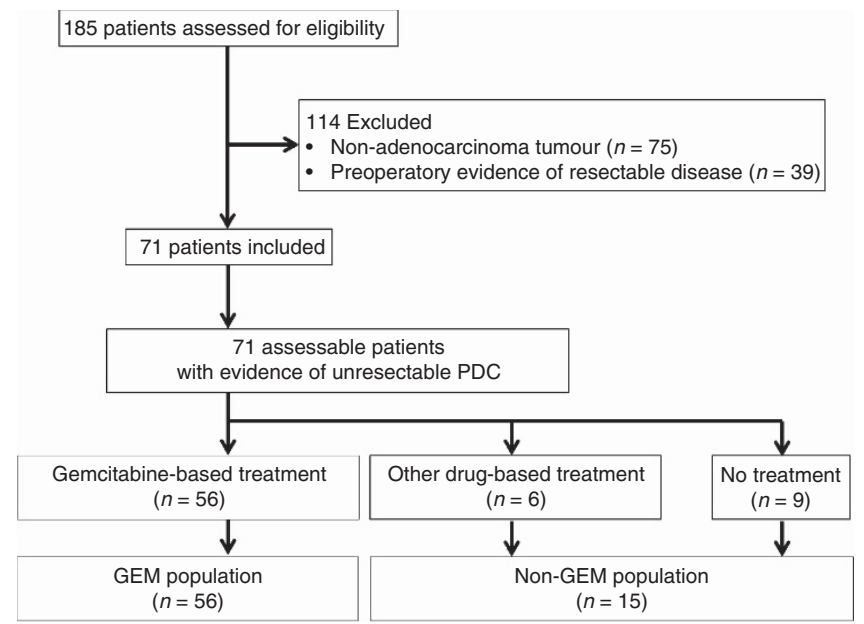

Figure 1. Flow diagram of the study participants. applied through the catheter connected to the needle using a 20-ml syringe, the needle was moved back and forth 10-20 times within the tumour. Negative pressure was released before the needle was removed from the lesion. To obtain sufficient tissue for RNA extraction and pathological diagnosis, several biopsy specimens were collected from each tumour by EUS-FNA using 22-G aspiration needles (EchoTip Ultra; Cook Japan, Tokyo, Japan). A cytologist immediately examined the specimens for cancer cells using part of the obtained tissue. We performed an additional one to two punctures after conventional diagnostic puncture to obtain adequate tissue for RNA extraction.

mRNA extraction. Tissue and blood collected from the obtained specimens were examined for confirmation of carcinoma cells by an on-site cytologist. The remaining tissue was instantly transferred to a $1.5-\mathrm{ml}$ micro test tube (Eppendorf, Saxony, Germany) and frozen at $-80{ }^{\circ} \mathrm{C}$ until use. The test tube that was used to inactivate the RNase was rinsed with $0.1 \mathrm{~N} \mathrm{NaOH} / 1 \mathrm{~mm}$ EDTA and diethylpyrocarbonate, and was stored at room temperature. Tissue samples were crushed in a mortar and placed on ice for RNA detection.Total RNA was isolated using the TRIzol Reagent method. Total RNA concentration was determined by spectrophotometer (NanoDrop2000c; Thermo, Tokyo, Japan), and $1 \mu \mathrm{g}$ total RNA was reverse transcribed using a Transcript First Strand

\begin{tabular}{|c|c|c|c|}
\hline & $\begin{array}{l}\text { GEM } \\
\text { population } \\
(n=56)\end{array}$ & $\begin{array}{l}\text { Non-GEM } \\
\text { population } \\
(n=15)\end{array}$ & $\begin{array}{l}P \text {-value } \\
\chi 2 \text { test }\end{array}$ \\
\hline $\begin{array}{l}\text { Median age in years (range) } \\
<69 \text { years } \\
>68 \text { years }\end{array}$ & $\begin{array}{l}69(37-88) \\
24(43 \%) \\
32(57 \%)\end{array}$ & $\begin{array}{l}68(49-84) \\
8(53 \%) \\
7(47 \%)\end{array}$ & 0.023 \\
\hline \multicolumn{4}{|l|}{ Sex } \\
\hline $\begin{array}{l}\text { Male } \\
\text { Female }\end{array}$ & $\begin{array}{l}26(46.4 \%) \\
30(53.6 \%)\end{array}$ & $\begin{array}{l}9(60 \%) \\
6(40 \%)\end{array}$ & 0.349 \\
\hline \multicolumn{4}{|l|}{ Location } \\
\hline $\begin{array}{l}\mathrm{Ph} \\
\mathrm{Pb} \text { and } \mathrm{Pt}\end{array}$ & $\begin{array}{l}24(42.9 \%) \\
32(57.1 \%)\end{array}$ & $\begin{array}{l}6(40 \%) \\
9(60 \%)\end{array}$ & 0.842 \\
\hline \multicolumn{4}{|l|}{ UICC TNM 7th f-stage } \\
\hline $\begin{array}{l}\text { Stage III } \\
\text { Stage IV }\end{array}$ & $\begin{array}{l}17(30.4 \%) \\
39(69.6 \%)\end{array}$ & $\begin{array}{r}3(20 \%) \\
12(80 \%)\end{array}$ & 0.346 \\
\hline \multicolumn{4}{|l|}{ Performance status } \\
\hline $\begin{array}{l}0 \\
1-3\end{array}$ & $\begin{array}{r}49(87.5 \%) \\
7(12.5 \%)\end{array}$ & $\begin{array}{r}11(73.3 \%) \\
4(26.7 \%)\end{array}$ & 0.201 \\
\hline \multicolumn{4}{|l|}{ Comorbidities } \\
\hline $\begin{array}{l}\text { Some } \\
\text { None }\end{array}$ & $\begin{array}{l}39(69.6 \%) \\
17(30.4 \%)\end{array}$ & $\begin{array}{r}11(73.3 \%) \\
4(26.7 \%)\end{array}$ & 0.779 \\
\hline \multicolumn{4}{|l|}{ GEM efficacy } \\
\hline $\begin{array}{l}\text { CR } \\
P R \\
\text { SD } \\
\text { PD }\end{array}$ & $\begin{array}{c}0(0 \%) \\
1(1.8 \%) \\
34(60.7 \%) \\
21(37.5 \%)\end{array}$ & & \\
\hline $\begin{array}{l}\text { No. of chemotherapy cycles, } \\
\text { median (range) }\end{array}$ & $4(1-31)$ & & \\
\hline \multicolumn{4}{|c|}{$\begin{array}{l}\text { Abbreviations: } \mathrm{CR}=\text { complete response; } \mathrm{GEM}=\text { gemcitabine; } \mathrm{Pb}=\text { body of the pancreas; } \\
\mathrm{PD}=\text { progressive disease; } \mathrm{Ph}=\text { head of the pancreas; } \mathrm{PR}=\text { partial response; } \mathrm{Pt}=\text { tail of the } \\
\text { pancreas; } \mathrm{SD}=\text { stable disease; } \mathrm{TNM}=\text { tumour node metastasis; } \mathrm{UICC}=\text { Unio Internationalis } \\
\text { Contra Cancrum. }\end{array}$} \\
\hline
\end{tabular}



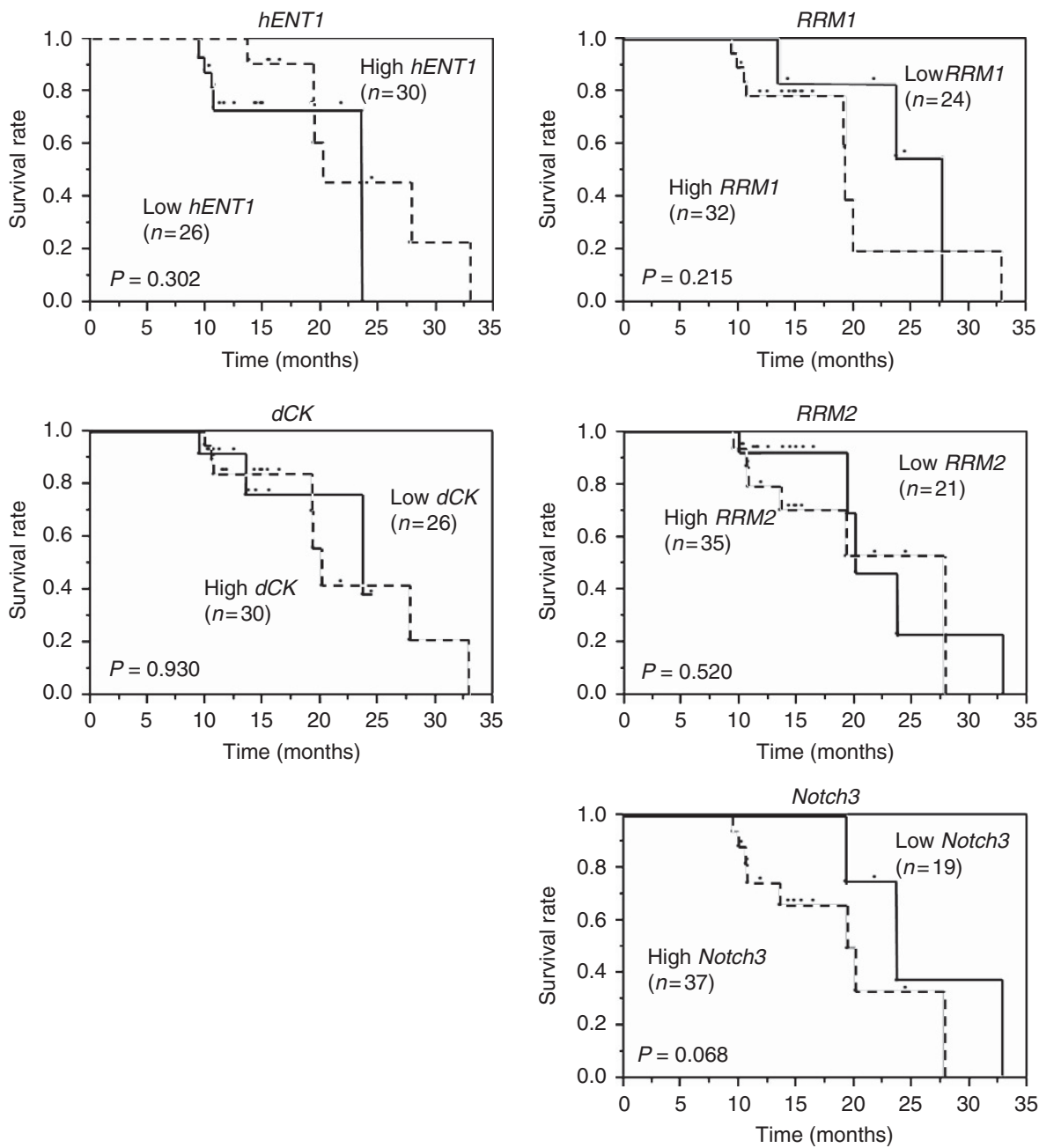

Figure 2. Kaplan-Meier curves of survival in the GEM-treated population according to each mRNA expression level. Each mRNA expression level was assigned to high or low using the median as a threshold.

cDNA Synthesis kit (Roche Diagnostics KK, Tokyo, Japan). Quantification of the target cDNA and an internal reference gene ( $\beta 2$-microglobulin, $\beta 2 M)$ was conducted by quantitative real-time reverse transcription-polymerase chain reaction (qRT-PCR).

qRT-PCR. We designed specific primers using Primer-BLAST (NCBI, http://www.ncbi.nlm.nih.gov/tools/primer-blast/). The following primers were used for real-time PCR: $d C K$ - forward primer, 5'-TCAAGCCACTCCAGAGACATGCTT- $3^{\prime}$; reverse primer, $5^{\prime}$-TG TCCTATGCAGGAGCCAGCTTTCA- $3^{\prime}$; $h E N T 1$ - forward primer, $5^{\prime}$-GGCCCAAGAAAGTGAAGCCA-3'; reverse primer, $5^{\prime}$-ACCAC TCAGGATCACCCCTG- ${ }^{\prime}$; RRM1 - forward primer, $5^{\prime}$-TCAAG GTGGGAACAAGCGTC-3'; reverse primer, $5^{\prime}$-CGCTGCTCTTCC TTTCCTGT-3'; RRM2 - forward primer, $5^{\prime}$-ACGGAGCCGAAAA CTAAAGCAGCT-3'; reverse primer, $5^{\prime}$-AGAGTCCACCTCCTC GGCG-3'; and Notch 3 - forward primer, $5^{\prime}$-TCCAGATTCTCATC CGAAACCGCT-3'; reverse primer, 5'-GGGTCTCCTCCTTGCT ATCCTGCAT- $3^{\prime}$. qRT-PCR was performed using a Rotor-Gene Q (Qiagen, Hilden, Germany) for 40 cycles at $95^{\circ} \mathrm{C}$ for $5 \mathrm{~s}$ and $60^{\circ} \mathrm{C}$ for $10 \mathrm{~s}$ using a SYBR Green PCR Master Mix (Qiagen), according to the manufacturer's instructions. Quantification was performed using the relative standard curve method. The standard curve was created automatically by Rotor-Gene $\mathrm{Q}$ by plotting the threshold cycle $\left(C_{\mathrm{t}}\right)$ against each input amount (containing $10^{7}, 10^{6}, 10^{5}, 10^{4}, 10^{3}, 10^{2}$ and $10^{1}$ copies) of standard plasmid DNA. The standard plasmid
DNA was created by direct cloning using a TA cloning vector and the PCR product generated using the specific primers described above and checked by sequencing. The correlation coefficient determined by linear regression $(r)$ for each standard curve was $>0.990$. The relative amount of each unknown sample was calculated by linear regression analysis from the respective standard curve. A relative target gene expression value for $\beta 2 M$ was used as an internal reference gene.

Target mRNA. Expressions of $d C K, h E N T 1, R R M 1, R R M 2$ and Notch3 were examined as genetic predictive markers associated with GEM transport and metabolism.

Statistical analyses. The primary end point was survival in GEMtreated patients with unresectable PDC according to the expression levels of the examined genes. The cutoff for analysis of survival was 30 April 2011. The secondary end point was time to progression (TTP) in the patients. Survival and TTP curves were estimated using the Kaplan-Meier technique. Differences between the survival curves and those between TTP curves were assessed using the log-rank test. The Cox proportional hazard regression model was used for multivariate analyses of survival and for estimating hazard ratios (HRs) with 95\% confidence intervals (CIs). The $\chi^{2}$ test was used to compare proportions. Statistical analyses were performed after dichotomising subgroups as follows: $h E N T 1$ low $v s$ high, $d C K$ low vs high, RRM1 low vs high, RRM2 low vs high 

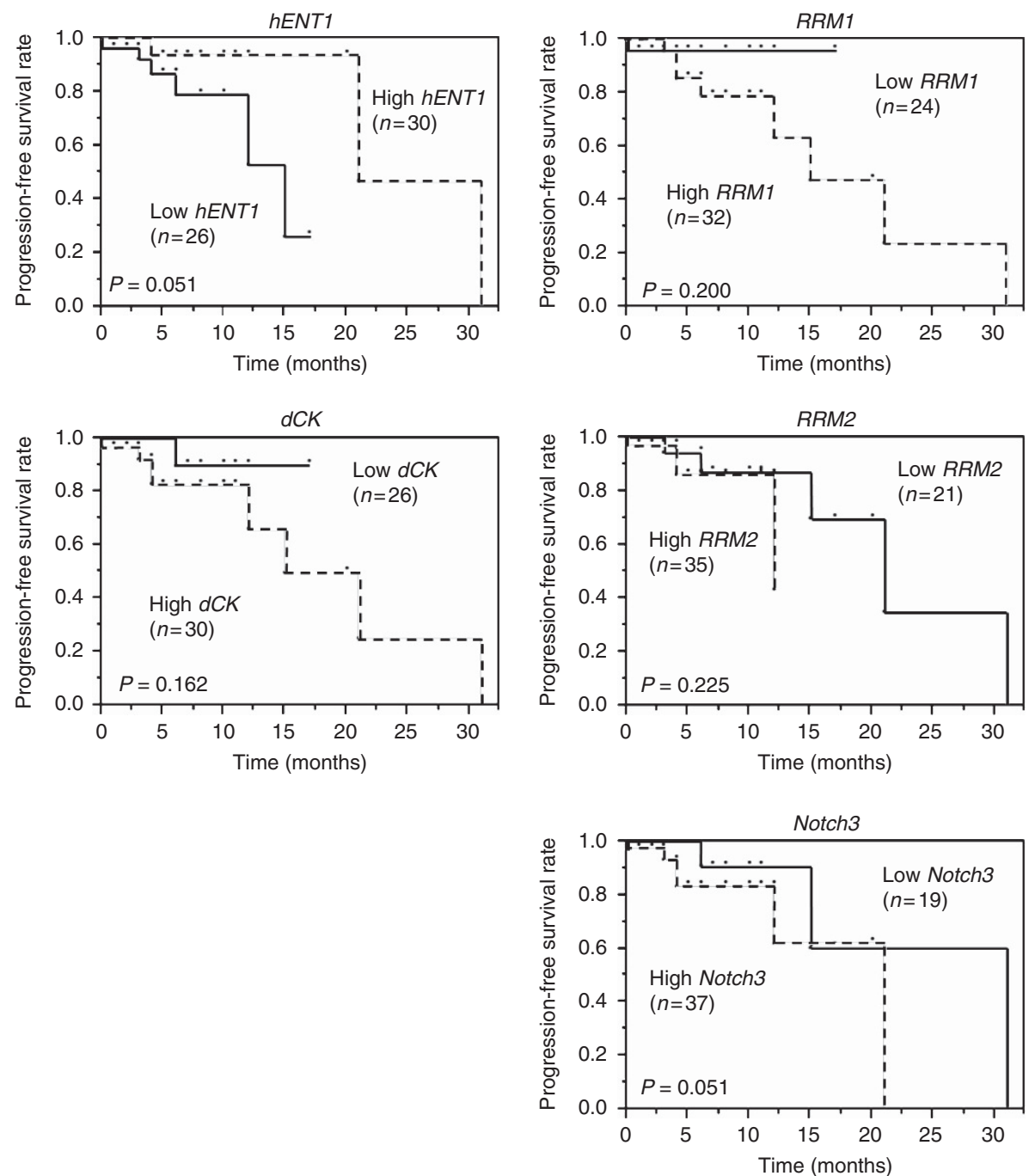

Figure 3. Kaplan-Meier curves of progression-free survival in the GEM-treated population according to each mRNA expression level. Each mRNA expression level was assigned to high or low using the median as a threshold.

and Notch3 low vs high. The thresholds were determined by the median of the mRNA expression in each of the 71 patients.

A value of $P<0.05$ was considered to indicate statistical significance. All statistical analyses were performed using JMP ver. 9.0 software (SAS Institute, Cary, NC, USA).

This study was carried out in accordance with the Institutional Review Board guidelines (Hokkaido University Hospital, Sapporo, Japan; clinical research approval number 010-0152), and written informed consent was obtained from all patients.

\section{RESULTS}

Patient characteristics. The clinical characteristics of the 56 patients who received GEM-based chemotherapy (GEM population) and the 15 who did not (non-GEM population) are shown in Table 1. There was no significant difference between the groups for all clinical characteristics other than age $(<69$ years $v s>68$ years $=69$ vs $68, P=0.023)$.

mRNA expression. Total RNA was successfully extracted from all specimens from the patients. The mean RNA concentration was $124 \pm 85 \mathrm{ng}^{-1} \mathrm{l}^{-1}$ (mean \pm s.d.) (range 13.2-478.8). The mean $d C K$, hENT1, RRM1, RRM2 and Notch 3 mRNA levels relative to the $\beta 2 M$ internal reference gene were $63 \pm 79$ (range 0-546), $590 \pm 620$
$(5-3178), \quad 576 \pm 3973 \quad(0.3-41508), \quad 757 \pm 2195 \quad$ (5-13 286), $242 \pm 629$ (0-4490), respectively.

Association between OS and mRNA expression levels in patients treated with GEM. Patients with low Notch3 mRNA levels tended to have a better prognosis than those with high Notch 3 mRNA level (low vs high $=23.6$ vs 19.3 months, $P=0.068$ ). However, there were no tendencies and no significant differences in OS between patients with low and high mRNA levels of $h E N T 1$ (low $v s$ high $=23.6$ vs 20 months, $P=0.302$ ), $d C K$ (low vs high $=23.6$ vs 20 months, $P=0.930$ ), RRM1 (low $v s$ high $=27.7$ vs 19.3 months, $P=0.215$ ) and $R R M 2$ (low $v s$ high $=20$ vs 27.7 months, $P=0.520$ ) (Figure 2).

Association between TTP and mRNA expression levels in the GEM-treated population. Patients with high hENT1 (low vs high $=15$ vs 21 months, $P=0.051$ ) or low Notch3 (low vs high $=31$ vs 21 months, $P=0.051)$ mRNA levels had longer TTP than patients with low hENT1 or high Noch 3 mRNA levels. In contrast, there were no differences in TTP between patients with low and high mRNA levels of $d C K(P=0.162), R R M 1(P=0.200)$ and RRM2 $(P=0.225)$ (Figure 3$)$.

Factors associated with OS of all patients with unresectable pancreatic cancer. Multivariate analysis for survival of all patients with unresectable PDC based on the Cox proportional hazard 
model was performed on all parameters described in Table 2. Survival was significantly associated with Notch3 expression levels (HRs, high $v s$ low $=1.00$ vs $0.0255, P=0.0094$ ) (Table 2). Although a significant difference was not observed, a tendency for the prognosis to be long was seen in patients with high hENT1 expression levels (HRs, high vs low $=1.00$ vs $29.9 P=0.074$ ). Interaction tests for GEM administration and hENT1 or Notch 3 mRNA expression levels were statistically significant $(P=0.0054$ and 0.0047 , respectively). Furthermore, we examined predictors of TTP in all patients. Multivariate analysis for TTP based on the Cox proportional hazard model was also performed on all parameters described in Table 3. A high hENT1 expression level was significantly associated with a long TTP (high $v s$ low $=1.00 v s$ 29.9; $P=0.039$ ) (Table 3).

\section{DISCUSSION}

In this retrospective study, we demonstrated that the expression levels of the hENT1 and Notch 3 genes are promising predictive markers for GEM responsiveness in patients with unresectable PDC. The possibility that Notch 3 was a prognostic predictive factor was considered on the basis of the results shown in Table 2. Furthermore, the possibility that $h E N T 1$ was a predictive of GEM responsiveness was suggested by the results shown in Table 3. Interaction tests involving these two genes supported the possibility that they are predictive of GEM responsiveness.

Human equilibrative nucleoside transporter 1 is a major GEM transporter that is overexpressed in pancreatic cancer cells (GarciaManteiga et al, 2003). The expression of hENT1 mRNA in resected specimens from patients with pancreatic cancer is associated with long OS, DFS and time to disease progression (Giovannetti et al, 2006; Farrell et al, 2009; Maréchal et al, 2012). Our results of multivariable analysis and interaction testing are compatible with the findings of previous reports. However, owing to the limitation represented by the small non-GEM-treated population, we could not compare Kaplan-Meier curves of the non-GEM population $v s$ those of the GEM-treated population.

Notch 3 plays important roles in the control of cell extracellular interactions, such as spreading, migration, motility and survival in pancreatic cancer cells (Dang et al, 2006). The Notch signalling pathway is involved in the acquisition of the epithelialmesenchymal transition (EMT) phenotype related to invasion of pancreatic cancer cells, and downregulation of Notch signalling is associated with decreased invasive behaviour of pancreatic cancer cells, followed by partial reversal of the EMT phenotype (Wang et al, 2009). In previous reports regarding resected PDC specimens, Notch 3 was frequently overexpressed in PDC lesions compared with normal pancreatic ductal tissue (Doucas et al, 2008). Meanwhile, nuclear Notch3 expression was clinically correlated with a lower OS time of PDC patients (Doucas et al, 2008) and also other carcinomas such as ovarian carcinoma (Park et al, 2010). In addition, it was reported that suppression of Notch 3 expression decreased the average half-maximal inhibitory concentration $\left(\mathrm{IC}_{50}\right)$ of GEM in pancreatic cell lines (Yao and Qian, 2010). Thus, there may be at least two pathways for the GEM effect: suppression of Notch 3 expression by GEM and amplification of the GEM effect through the suppression of Notch3.

To date, there has been no report of the relationship between the effectiveness of GEM and Notch 3 mRNA expression in the clinical course of PDC. For the first time, our results using pre-treated EUS-FNA specimens suggest that Notch3 is a promising informative biomarker for predicting the effectiveness of GEM and GEM sensitivity in patients with unresectable PDC. Using Kaplan-Meier analysis of OS and TTP and multivariate analysis for OS, our expression data and clinical results might be

\begin{tabular}{|c|c|c|c|c|}
\hline & \multicolumn{4}{|c|}{ Multivariate analysis (survival) } \\
\hline $\begin{array}{l}\text { Patient } \\
\text { stratification }\end{array}$ & n & HR & $95 \% \mathrm{Cl}$ & $\boldsymbol{P}$-value \\
\hline \multicolumn{5}{|l|}{ Age (years) } \\
\hline$<69 / \geqslant 69$ & $32 / 39$ & $1 / 3.83$ & $0.44-68.0$ & 0.229 \\
\hline \multicolumn{5}{|l|}{ Sex } \\
\hline Female/male & $36 / 35$ & $1 / 0.154$ & $0.011-1.12$ & 0.06 \\
\hline \multicolumn{5}{|l|}{ Location } \\
\hline $\mathrm{Ph} / \mathrm{Pb}$ and $\mathrm{Pt}$ & $30 / 41$ & $1 / 7.31$ & $0.29-728$ & 0.244 \\
\hline \multicolumn{5}{|c|}{ UICC TNM 7th f-stage } \\
\hline III/IV & $21 / 50$ & $1 / 0.0384$ & $0.000347-0.734$ & 0.0275 \\
\hline \multicolumn{5}{|c|}{ Performance status } \\
\hline $0 / 1-3$ & $65 / 11$ & $1 / 0.000127$ & 0-117429839 & 0.995 \\
\hline \multicolumn{5}{|l|}{ Comorbidities } \\
\hline Some/none & $50 / 21$ & $1 / 0.0557$ & $0.0007-0.682$ & 0.020 \\
\hline \multicolumn{5}{|l|}{ GEM-treated } \\
\hline Yes/no & $56 / 15$ & $1 / 0.209$ & $0.00204-8.75$ & 0.419 \\
\hline \multicolumn{5}{|l|}{ hENT1 } \\
\hline High/low & $33 / 38$ & $1 / 29.9$ & $0.730-2918$ & 0.074 \\
\hline \multicolumn{5}{|l|}{ dCK } \\
\hline High/low & $38 / 33$ & $1 / 4.098$ & $0.371-61.8$ & 0.236 \\
\hline \multicolumn{5}{|l|}{ RRM1 } \\
\hline High/low & $37 / 34$ & $1 / 0.515$ & $0.0174-20.1$ & 0.702 \\
\hline \multicolumn{5}{|l|}{ RRM2 } \\
\hline High/low & $39 / 32$ & $1 / 1.64$ & $0.117-56.0$ & 0.733 \\
\hline \multicolumn{5}{|l|}{ Notch3 } \\
\hline High/low & $43 / 28$ & $1 / 0.0255$ & $0.0000483-0.503$ & 0.0094 \\
\hline \multicolumn{5}{|c|}{$\begin{array}{l}\text { Abbreviations: } \mathrm{Cl}=\text { confidence interval; } \mathrm{dCK}=\text { deoxycitidine kinase; } \mathrm{GEM}=\text { gemcitabine; } \\
\mathrm{hENT} 1=\text { human equilibrative nucleoside transporter } 1 ; \mathrm{HR}=\text { hazard ratio; } \mathrm{N}=\text { number; } \\
\mathrm{Pb}=\text { body of the pancreas; } \mathrm{PDC}=\text { pancreatic ductal carcinoma; } \mathrm{Ph}=\text { head of the pancreas; } \\
\mathrm{Pt}=\text { tail of the pancreas; RRM1 = ribonucleoside reductase } 1 ; \mathrm{RRM} 2=\text { ribonucleoside } \\
\text { reductase } 2 \text {. }\end{array}$} \\
\hline
\end{tabular}

used to address the results of patients with low Notch 3 mRNA levels compared to patients with high levels. However, further study in more patients is needed to confirm this correlation.

Endoscopic ultrasound-guided fine-needle aspiration is widely used as a cytological and histological sample collection tool for pancreatic cancer (Takahashi et al, 2005; Khalid et al, 2006), and there have been some reports of oncogene analysis in pancreatic cancer using EUS-FNA samples (Tada et al, 2002; Buchholz et al, 2005; Khalid et al, 2006; Ashida et al, 2009). The reliability of tests based on tissue or cell extracts is often dependent on the relative abundance of the target cell population. Moreover, sampling errors or a large number of 'contaminating cells' can lead to false-negative results (Fujita et al, 2008). This is likely why Fujita et al (2010) were unable to detect significant differences in mRNA levels among 
Table 3. Multivariate analysis of progression of disease in the GEM population

Multivariate analysis (progression)

\begin{tabular}{|l|c|c|c|c|}
\hline Patient stratification & $n$ & HR & $95 \%$ Cl & P-value \\
\hline Age (years) & $29 / 27$ & $1 / 1.42$ & $0.0427-54.1$ & 0.836 \\
\hline$<69 / \geqslant 69$ & $30 / 26$ & $1 / 0.396$ & $0.0121-5.62$ & 0.501 \\
\hline Sex & $24 / 32$ & $1 / 1.35$ & $0.0137-3848$ & 0.908 \\
\hline Female/male & & \\
\hline Location & $18 / 38$ & $1 / 0.687$ & $0.000491-50.7$ & 0.873 \\
\hline Ph/Pb and Pt &
\end{tabular}

\section{Performance status}

\begin{tabular}{|l|c|c|c|c|}
\hline $0 / 1-3$ & $49 / 7$ & $1 / 54.7$ & $0.777-14312$ & 0.064 \\
\hline Comorbidities & $39 / 17$ & $1 / 0.281$ & $0.00541-3.94$ & 0.374 \\
\hline Some/none
\end{tabular}

TMs decline

\begin{tabular}{|l|l|l|l|l|}
\hline$<50 \% / \geqslant 50 \%$ & $32 / 24$ & $1 / 0.906$ & $0.0558-13.0$ & 0.939 \\
\hline
\end{tabular}

\section{hENT1}

\begin{tabular}{|l|l|l|l|l|}
\hline High/low & $30 / 26$ & $1 / 29.9$ & $1.13-8605$ & 0.039 \\
\hline dCK & $30 / 26$ & $1 / 0.199$ & $0.00503-2.70$ & 0.238 \\
\hline High/low & $32 / 24$ & $1 / 0.180$ & $0.00187-3.53$ & 0.278 \\
\hline RRM1 &
\end{tabular}

RRM2

\begin{tabular}{|l|l|l|l|l|}
\hline High/low & $35 / 21$ & $1 / 4.63$ & $0.155-641$ & 0.393 \\
\hline Notch3 & $38 / 18$ & $1 / 0.233$ & $0.000862-8.00$ & 0.460 \\
\hline High/low
\end{tabular}

Abbreviations: $\mathrm{Cl}=$ confidence interval; $\mathrm{dCK}=$ deoxycitidine kinase; $\mathrm{GEM}=$ gemcitabine; hENT1 = human equilibrative nucleoside transporter $1 ; \mathrm{HR}=$ hazard ratio; $\mathrm{N}=$ number; $\mathrm{Pb}=$ body of the pancreas; $\mathrm{Ph}=$ head of the pancreas; $\mathrm{Pt}=$ tail of the pancreas; RRM1 = ribonucleoside reductase $1 ; \mathrm{RRM} 2=$ ribonucleoside reductase $2 ; \mathrm{TMs}=$ tumour markers.

whole-cell pellet samples; however, they could distinguish higher and lower expression of each gene among neoplastic cell samples by microdissection. In this, we could distinguish higher and lower expression of genes by selection of white tissue on site, although we used total RNA isolated from EUS-FNA tissue samples without microdissection. It may be important to trim white tissue for high-quality RNA analysis, although there is no evidence to support this. In addition, some reports suggest that flow cytometry and cytogenetic analysis or improvement of diagnostic accuracy using specimens of EUS-FNA could be achieved using a thick 19-G needle instead of a 22- or 25-G needle puncture (Yasuda et al, 2012). Therefore, further development of methods for sample collection and processing are required to improve wide genetic analysis of EUS-FNA specimens.
If GEM sensitivity could be predicted using specimens collected by EUS-FNA at the same time as pathological diagnosis, the appropriate anticancer agents such as oxaliplatin, irinotecan, fluorouracil and leucovorin (FOLFIRINOX) could be selected (Conroy et al, 2011). Furthermore, based on the results of RNA analyses of EUS-FNA specimens, the appropriate preoperative neoadjuvant chemotherapy could be administered.

There are several limitations to our study. One is that the sample size and observation period were not sufficient, and the other is that this was a retrospective and single centre study. To address these issues, a large-scale, multicentre prospective study is needed.

In conclusion, based on genetic analysis of EUS-FNA tissue samples, our data suggest that hENT1 and Notch3 mRNA expression levels are promising novel and informative biomarkers for predicting and monitoring $G$ sensitivity in patients with unresectable PDC.

\section{ACKNOWLEDGEMENTS}

We thank Mr K Marukawa (Department of Surgical Pathology, Hokkaido University Hospital) for skilful cytologic examination and analysis. We also thank Dr Y Hatanaka (Department of Surgical Pathology, Hokkaido University Hospital) for skilful examination and analysis, and Dr K. Ooba (Clinical Trial Centre, Hokkaido University Hospital) for conducting the statistical analyses. This study was financially supported by the Pancreas Research Foundation Japan (HK).

\section{CONFLICT OF INTEREST}

The authors declare no conflict of interest.

\section{AUTHOR CONTRIBUTIONS}

HK managed the patients and performed the endoscopic examination; KE and HK designed the research and provided discussion; KE, AT and MF performed tissue preparation and analysed the data; KE and HK analysed the data; MK, TK, SK and YA analysed the data and provided clinical advice; YM diagnosed the case of pathology; KE and HK collected the data and wrote the paper; and MA and NS supervised the research. All authors approved the final manuscript for publication.

\section{REFERENCES}

Ashida R, Nakata B, Shigekawa M, Mizuno N, Sawaki A, Hirakawa K, Arakawa T, Yamao K (2009) Gemcitabine sensitivity-related mRNA expression in endoscopic ultrasound-guided fine-needle aspiration biopsy of unresectable pancreatic cancer. J Exp Clin Cancer Res 28: 83.

Buchholz M, Kestler HA, Bauer A, Böck W, Rau B, Leder G, Kratzer W, Bommer M, Scarpa A, Schilling MK, Adler G, Hoheisel JD, Gress TM (2005) Specialized DNA arrays for the differentiation of pancreatic tumors. Clin Cancer Res 11(22): 8048-8054.

Burris HA, Moore MJ, Andersen J, Green MR, Rothenberg ML, Modiano MR, Cripps MC, Portenoy RK, Storniolo AM, Tarassoff P, Nelson R, Dorr FA, Stephens CD, Von Hoff DD (1997) Improvements in survival and clinical benefit with gemcitabine as first-line therapy for patients with advanced pancreas cancer: a randomized trial. J Clin Oncol 15(6): 2403-2413.

Conroy T, Desseigne F, Ychou M, Bouché O, Guimbaud R, Bécouarn Y, Adenis A, Raoul JL, Gourgou-Bourgade S, de la Fouchardière C, Bennouna J, Bachet JB, Khemissa-Akouz F, Péré-Vergé D, Delbaldo C, Assenat E, Chauffert B, Michel P, Montoto-Grillot C, Ducreux M. Groupe Tumeurs Digestives of Unicancer; PRODIGE Intergroup (2011) FOLFIRINOX 
versus gemcitabine for metastatic pancreatic cancer. N Engl J Med 364(19): $1817-1825$.

Dang L, Fan X, Chaudhry A, Wang M, Gaiano N, Eberhart CG (2006) Notch3 signaling initiates choroid plexus tumor formation. Oncogene 25(3): 487-491.

Doucas H, Mann CD, Sutton CD, Garcea G, Neal CP, Berry DP, Manson MM (2008) Expression of nuclear Notch3 in pancreatic adenocarcinomas is associated with adverse clinical features, and correlates with the expression of STAT3 and phosphorylated Akt. J Surg Oncol 97(1): 63-68.

Farrell JJ, Elsaleh H, Garcia M, Lai R, Ammar A, Regine WF, Abrams R, Benson AB, Macdonald J, Cass CE, Dicker AP, Mackey JR (2009) Human equilibrative nucleoside transporter 1 levels predict response to gemcitabine in patients with pancreatic cancer. Gastroenterology 136(1): 187-195.

Fujita H, Ohuchida K, Mizumoto K, Egami T, Miyasaka Y, Yamaguchi H, Yu J, Cui L, Onimaru M, Takahata S, Tsuneyoshi M, Tanaka M (2008) Quantitative analysis of hTERT mRNA levels in cells microdissected from cytological specimens. Cancer Sci 99(11): 2244-2251.

Fujita H, Ohuchida K, Mizumoto K, Itaba S, Ito T, Nakata K, Yu J, Kayashima T, Souzaki R, Tajiri T, Manabe T, Ohtsuka T, Tanaka M (2010) Gene expression levels as predictive markers of outcome in pancreatic cancer after gemcitabine-based adjuvant chemotherapy. Neoplasia 12(10): 807-817.

Garcia-Manteiga J, Molina-Arcas M, Casado FJ, Mazo A, Pastor-Anglada M (2003) Nucleoside transporter profiles in human pancreatic cancer cells: role of hCNT1 in $2^{\prime}, 2^{\prime}$-difluorodeoxycytidine-induced cytotoxicity. Clin Cancer Res 9(13): 5000-5008.

Giovannetti E, Del Tacca M, Mey V, Funel N, Nannizzi S, Ricci S, Orlandini C, Boggi U, Campani D, Del Chiaro M, Iannopollo M, Bevilacqua G, Mosca F, Danesi R (2006) Transcription analysis of human equilibrative nucleoside transporter-1 predicts survival in pancreas cancer patients treated with gemcitabine. Cancer Res 66(7): 3928-3935.

Itoi T, Sofuni A, Fukushima N, Itokawa F, Tsuchiya T, Kurihara T, Moriyasu F, Tsuchida A, Kasuya K (2007) Ribonucleotide reductase subunit M2 mRNA expression in pretreatment biopsies obtained from unresectable pancreatic carcinomas. J Gastroenterol 42(5): 389-394.

Itoi T, Takei K, Sofuni A, Itokawa F, Tsuchiya T, Kurihara T, Nakamura K, Moriyasu F, Tsuchida A, Kasuya K (2005) Immunohistochemical analysis of p53 and MIB-1 in tissue specimens obtained from endoscopic ultrasonography-guided fine needle aspiration biopsy for the diagnosis of solid pancreatic masses. Oncol Rep 13(2): 229-234.

Khalid A, Nodit L, Zahid M, Bauer K, Brody D, Finkelstein SD, McGrath KM (2006) Endoscopic ultrasound fine needle aspirate DNA analysis to differentiate malignant and benign pancreatic masses. Am J Gastroenterol 101(11): 2493-2500.

Maréchal R, Bachet JB, Mackey JR, Dalban C, Demetter P, Graham K, Couvelard A, Svrcek M, Bardier-Dupas A, Hammel P, Sauvanet A, Louvet C, Paye F, Rougier P, Penna C, André T, Dumontet C, Cass CE, Jordheim LP, Matera EL, Closset J, Salmon I, Deviere J, Emile JF, Van Laethem JL (2012) Levels of gemcitabine transport and metabolism proteins predict survival times of patients treated with gemcitabine for pancreatic adenocarcinoma. Gastroenterology 143(3): 664-674e6.

Maréchal R, Mackey JR, Lai R, Demetter P, Peeters M, Polus M, Cass CE, Salmon I, Deviere J, Van Laethem JL (2010) Deoxycitidine kinase is associated with prolonged survival after adjuvant gemcitabine for resected pancreatic adenocarcinoma. Cancer 116(22): 5200-5206.

Matsuno S, Egawa S, Fukuyama S, Motoi F, Sunamura M, Isaji S, Imaizumi T, Okada S, Kato H, Suda K, Nakao A, Hiraoka T, Hosotani R, Takeda K
(2004) Pancreatic Cancer Registry in Japan: 20 years of experience. Pancreas 28(3): 219-230.

Nakahira S, Nakamori S, Tsujie M, Takahashi Y, Okami J, Yoshioka S, Yamasaki M, Marubashi S, Takemasa I, Miyamoto A, Takeda Y, Nagano H, Dono K, Umeshita K, Sakon M, Monden M (2007) Involvement of ribonucleotide reductase M1 subunit overexpression in gemcitabine resistance of human pancreatic cancer. Int J Cancer 120(6): $1355-1363$.

Neoptolemos JP, Stocken DD, Friess H, Bassi C, Dunn JA, Hickey H, Beger H, Fernandez-Cruz L, Dervenis C, Lacaine F, Falconi M, Pederzoli P, Pap A, Spooner D, Kerr DJ, Büchler MW. Cancer ESGfP (2004) A randomized trial of chemoradiotherapy and chemotherapy after resection of pancreatic cancer. N Engl J Med 350(12): 1200-1210.

Oettle H, Post S, Neuhaus P, Gellert K, Langrehr J, Ridwelski K, Schramm H, Fahlke J, Zuelke C, Burkart C, Gutberlet K, Kettner E, Schmalenberg H, Weigang-Koehler K, Bechstein WO, Niedergethmann M, Schmidt-Wolf I, Roll L, Doerken B, Riess H (2007) Adjuvant chemotherapy with gemcitabine vs observation in patients undergoing curative-intent resection of pancreatic cancer: a randomized controlled trial. JAMA 297(3): 267-277.

Park JT, Chen X, Tropè CG, Davidson B, IeM Shih, Wang TL (2010) Notch3 overexpression is related to the recurrence of ovarian cancer and confers resistance to carboplatin. Am J Pathol 177(3): 1087-1094.

Tada M, Komatsu Y, Kawabe T, Sasahira N, Isayama H, Toda N, Shiratori Y, Omata M (2002) Quantitative analysis of K-ras gene mutation in pancreatic tissue obtained by endoscopic ultrasonography-guided fine needle aspiration: clinical utility for diagnosis of pancreatic tumor. Am J Gastroenterol 97(9): 2263-2270.

Takahashi K, Yamao K, Okubo K, Sawaki A, Mizuno N, Ashida R, Koshikawa T, Ueyama Y, Kasugai K, Hase S, Kakumu S (2005) Differential diagnosis of pancreatic cancer and focal pancreatitis by using EUS-guided FNA. Gastrointest Endosc 61(1): 76-79.

Wagner M, Redaelli C, Lietz M, Seiler CA, Friess H, Büchler MW (2004) Curative resection is the single most important factor determining outcome in patients with pancreatic adenocarcinoma. Br J Surg 91(5): 586-594.

Wang Z, Li Y, Kong D, Banerjee S, Ahmad A, Azmi AS, Ali S, Abbruzzese JL, Gallick GE, Sarkar FH (2009) Acquisition of epithelial-mesenchymal transition phenotype of gemcitabine-resistant pancreatic cancer cells is linked with activation of the notch signaling pathway. Cancer Res 69(6): 2400-2407.

Yao J, Qian C (2010) Inhibition of Notch3 enhances sensitivity to gemcitabine in pancreatic cancer through an inactivation of PI3K/Akt-dependent pathway. Med Oncol 27(3): 1017-1022.

Yasuda I, Goto N, Tsurumi H, Nakashima M, Doi S, Iwashita T, Kanemura N, Kasahara S, Adachi S, Hara T, Shimizu M, Takami T, Moriwaki H (2012) Endoscopic ultrasound-guided fine needle aspiration biopsy for diagnosis of lymphoproliferative disorders: feasibility of immunohistological, flow cytometric, and cytogenetic assessments. Am J Gastroenterol 107(3): 397-404.

This work is published under the standard license to publish agreement. After 12 months the work will become freely available and the license terms will switch to a Creative Commons AttributionNonCommercial-Share Alike 3.0 Unported License. 